
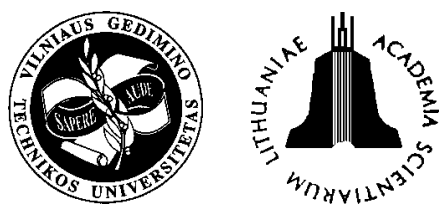

ISSN 1648-4142 TRANSPORT

http:/www.vtu.lt/english/editions

\title{
THE RESEARCH INTO THE DEVELOPMENT OF PASSENGER TRANSPORT BY LAND*)
}

\author{
Jonas Butkevičius \\ Dept of Transport Management, Vilnius Gediminas Technical University, \\ Plytinès g. 27, LT-10105 Vilnius, Lithuania.E-mail:vladas@ti.vtu.lt
}

Received 2004-03-16; accepted 2004-06-30

\begin{abstract}
This is the first scientific work in Lithuania carrying out a complex research into passenger transport by land, covering all problematic issues related to the field such as development, market planning, organization, management, competition, contractual relations, financing, development of transport technologies, implementation of new transport technologies elaborating the theoretical base for the development of passenger transport.

The research shows the analysis of the movement of passenger transport volumes and determines the regularity of these changes.

The forecast of passenger transport by land is based on a multiple analysis.

The work determines the perspective markets of rail and road transport as well as elaborates the principles of the improvement of road and rail transport interaction.

The author originates the principles of the development of passenger transport technologies and the principles of the implementation of advanced technologies.

The author also founds the principles of planning, organization and management of land transport as well as the principles of security of equal conditions of competition and contractual relations between customers and haulers.
\end{abstract}

Keywords: passenger transport, land transport, development problems, forecast, technologies of rail and road transport, transport market, passenger flow.

\section{Introduction}

Passenger transport is a significant branch of any country economy that ensures functioning of a country, its regions, cities or villages and international inhabitants' communication. About $9 \%$ of all workers are employed in Lithuanian transport sector. More than half of them work in passenger transport. It makes even $4 £ / o$ of all country workers.

Since the independence of Lithuania, still many problems have remained: conveying of passengers is developing chaotic; haulage technologies are not improved in practise, public surface transport network development is chaotic, road and railway transport markets are unspecified, transport modes of interaction are not investigated, planning and organising of public transport is not based on public demand investigation. Public transport problems are not investigated, complex tools for this transport development

*) The work was presented for the granting of the professor's degree. are not prepared. It means that the development of the haulage was not built on scientific research. Because of the above mentioned reasons trips by land passenger transport modes decreased considerably last decade, the quality of passenger service is poor, etc.

These problems are even more intense when Lithuania is preparing to become a member of the $\mathrm{EU}$, because it is necessary to reorganize country transport, at the same time - passenger haulages according to theEU requirements. It is necessary, as well, to integrate the international passenger transport system into common European passenger transport market.

However, not many passenger transport issues were investigated so far in Lithuania. It should be emphasized that passenger transport development has been chaotic, in many cases not based on scientific research.

So, the investigations of the development of passenger transportation by land transport based on systematic generalisation of scientific research that high- 
light consistent patterns of the transportation development, reveal transportation problems and their reasons, describe perspective markets for road and railway transport, define principles of road and railway transport interaction, ways for renewal of vehicles, determine up-to-date principles for the improvement of planning, organising, management and financing of public transport, create scientific fundamentals for the improvement and introduction of passenger transportation technologies, are timely and relevant.

\section{Forecast of volume passenger transportation}

The analysis and forecast of transportation is one of the goals of National Programme of Transport Development. This is a complicated problem which has not, however, been discussed much in publications of our country and abroad.

Developing econometric models a researcher is usually faced with a great number of variables and a small number of observations. If only some of them are considered, the obtained data will not be correct. Therefore, one of the most suitable approaches may be the application of multiple regression analysis [1]

If there is relationship between the variables $t$, $x, z$, for example, $t$ - time periods, $x$ - gross national product (GNP), $z$ - national income and $y$ - number of passengers, then, we get:

$$
y^{\prime}=a t^{2}+b t+c x^{2}+d x+e z^{2}+f z+g .
$$

When the regression parameters $a, b, c, d, e, f$ and $g$ are calculated, a system of seven equations is solved.

The calculations show that national income is the most suitable parameter for making passenger traffic forecast, compared with other parameters including gross national product, monthly work payment, household income and expenditures, national wealth, production and users' cost index and variation of consumer goods and services.

It is predicted that passenger traffic by land transport will grow up to $575 \mathrm{~m}$ people by 2010 , while by 2015 it will reach $893 \mathrm{~m}$ people, i.e. it will increase by about 1,6 and 2,6 times, respectively, compared with passenger traffic in 2001.

It is predicted that by 2010 urban passenger transportation by bus and by trolley-bus will grow up to $220 \mathrm{~m}$ and $286 \mathrm{~m}$ passengers, respectively (compared with the number of passengers transported in 2001 it will grow by 1,5 and 1,6 times, respectively), while by 2015 it will increase to $344 \mathrm{~m}$ and $443 \mathrm{~m}$ people (compared with the figures for 2001 it will grow by 2,4 and by 2,4 times, respectively). Suburban passenger transportation by bus should grow up to $32 \mathrm{~m}$ people by 2010 , and up to $50 \mathrm{~m}$ people by
2015, implying that it will grow by 1,3 and 2,1 times, respectively, compared with the number of passengers transported in 2001.

It is predicted that by 2010 long-distance and international passenger transportation by bus will grow up to $16,9 \mathrm{~m}$ and $1,4 \mathrm{~m}$ people (compared with the data in 2001 it will increase by 1,44 and 1,42 times, respectively), while by 2015 it will increase to $26,4 \mathrm{~m}$ and 2,13 m people (compared with 2001 it will grow by 2,3 and 2,2 times, respectively).

It is predicted that by 2010 national and international passenger transportation by railway will grow up to 7,8 $\mathrm{m}$ and $2,1 \mathrm{~m}$ people (compared with 2001 it will grow by 1,2 and 1,5 times, respectively), while by 2015 it will reach 7,8 $\mathrm{m}$ and 2,1 m people (compared with 2001 it will grow by 1,2 and 1,5 times, respectively), and by 2015 it will reach $12,2 \mathrm{~m}$ and 3,2 $\mathrm{m}$ people (compared with 2001 the increase will be by 1,9 and 2,3 times, respectively).

The above forecasts were used in working out the strategies of national road and railway transportation development.

\section{The analysis of passengers' transportation by land market}

While evaluating the entire market of the country's passengers' transportation, it is evident that the impact of the transportation carried out by the internal waterways on this market is minimal and air transportation does not influence the country's internal market and occupies an insignificant share $12,8 \%$ of the international market. Having analysed the statistical data, we can state that the principal share of the county's passengers' transportation market is made up by land transport which carries $99,5 \%$ of all the passengers, $99,6 \%$ of the internal passengers and $84,8 \%$ of the international ones. Hence, it is a matter of utmost importance of this kind of transport [2].

The analysis of the city's (urban) transport market shows that in 1995 bus transportation in the cities made up $47,0 \%$ of the overall country's internal transportation, trolley-buses constituted $39,2 \%$ of the internal transportation. In 2001 bus and trolley-bus transportation in the cities constituted $51,3 \%$ and $46,5 \%$ of the overall internal transportation correspondingly. In 1995 passengers' transportation in the cities constituted $88,2 \%$ of the overall passengers' transportation by road whereas in 2001 urban public transportation amounted to $90,1 \%$.

In 2001 the intercity passengers' transportation by bus made up 3,1\% of the overall country's internal transportation and 3,2\% of all the country's internal transportation by road. 
In 1995 and 2001 passengers' transportation by rail amounted only $2,2 \%$ of the overall country's passengers' transportation.

In 1995 local passengers' transportation by rail made up $1,9 \%$ of the all country's internal passengers' transportation whereas in 2001 it was only 1,8\%.

In 1995 international passengers' transportation by rail constituted $56,5 \%$ of all the country's international transportation whereas in 2001 its share went down to $49,7 \%$.

It should be emphasized that Lithuania serves as the platform by which a transit railway passengers' stream flows from Kaliningrad to Russia. Therefore it is crucial to distinguish passengers' flows to/from the country and transit flows. In $199548,9 \%$ of all the international railway passengers' flows were to/ from the country whereas in 2001 their share decreased to $14,4 \%$. As we see transit railway passengers' flows constituted 51,1\% in 1995 and amounted to $85,6 \%$ in 2001 .

Since 1995 the amount of passengers using the country's railway services and their share of railway transport market is steadily decreasing due to various reasons. As in the whole Europe the Lithuanian people's income is growing, especially of urban residents and there is an increasing number of privately owned automobiles. In the period of 1990-2001 their amount went up from 128 to 304 for 1000 country's resident, i.e. it increased by 2,4 times. It is feasible that this tendency will remain in the future altogether with the population's growing purchasing power if drastic measures are not taken. The basic reasons for such a decline are associated with the decreasing of railway services (slow speed, old carriages, lack of comfort and privacy).

Moreover, buses and private automobiles are much more convenient not only for the people living in the villages, but also for those living o long way from railway stations (15-20 min or longer) and having to commute to work or school.

In many cases buses and certainly cars ensure greater comfort and shorter time as compared with uncomfortable, old and slow trains which are the result of the insufficient infrastructure. Anyway privately - owned automobiles and public buses in Lithuania, as it is observed everywhere in Europe, will be the main competitors of the railway services. As far as the international interconnection is concerned there will be a constant increase in the competitiveness of the air services.

Market peculiarities of passengers' transportation determined by these investigations revealed the necessity to carry out an analytic problem analysis. But the analysis should be based on theoretical preconditions.

\section{The research into the distribution of passenger transportations in accordance with various means of transport among Lithuania's main cities}

The distribution of the intercity passengers' flows carried by various means of transport is not investigated in Lithuania yet. However, this distribution is important identifying the passengers' transportation markets. This year in May the author carried out the research into the passenger flows among Lithuania's four biggest cities - Vilnius, Kaunas, Klaipeda and Siauliai. Daily direct flows from town to town by various means - bus, (including microbuses), train and car were examined $[3,4]$.

The conducted research into passenger flows revealed a number of interesting facts. First of all, fifteen years ago or more the main intercity passengers' flows were carried by rail or bus where nowadays as much as four-fifths, i.e. $81,3 \%$ of direct passengers' flows between theses cities are transported by cars. Buses transport only $14,9 \%$ of passengers and trains carry only a very small part, i.e. 3,8 \% of direct passengers from one city to another. For example, over $76,4 \%$ of passengers go by car from Vilnius to Kaunas and in the opposite direction. on analogy $80,6 \%$ of passengers travel between Vilnius and Šiauliai, 84,6\% between Vilnius and Klaipeda, 91,0\% of passengers - between Kaunas and Šiauliai, 85,8\% of passengers - between Kaunas and Klaipeda and 87,1 \% of passengers - between Šiauliai and Klaipeda.

Another important fact is that relatively small direct flows of passengers among these cities are transported by train only $3,8 \%$ of passengers.

One more interesting fact is that the daily flow of passengers going by car from Kaunas to Vilnius is twice as big than from Vilnius to Kaunas -3780 and 1525 correspondingly. It can be explained by the fact that the capital attracts bigger flows of people.

Another significant fact is relatively small occupancy of a car, it varies from 1,5 to 1,8 passengers in some directions (including the driver). As a result going by car becomes more expensive than going by train or bus. However, man still chooses this main means of transport. What are the factors determining such a choice?

Firstly it should be mentioned here that public transport has lost its attractiveness due to its slow communication speed and lack of comfort although in recent years comfort has gradually been improving in public transport. However, it is difficult to win back "the lost" passengers.

Another important fact in favour of a car is a possibility of travelling without having to change means, i.e. from "door to door" which in turn shortens the duration of a trip as compared to public trans- 
port. In the latter case a certain amount of time is wasted for getting to a railway or bus station and from here to the final point of destination. All these factors determine the priority use of a car in public transport.

Therefore the main task of intercity public railway and road transport is not only to compete with each other but mostly collaborate and, thus, "win the passengers back from their cars".

\section{The major ways of improving passenger transpor- tation as well as ways of developing the interaction between railway and road transport}

The author's research of several years standing [5-10] has shown that passengers' flows using local trains are insignificant - a diesel train is filled in up to $3-24 \%$, thus it is very uneconomical to use four-carriage diesel trains on these routes.

1. Having considered the results of the research, it has been proposed to use automotrises on unintensive routes carrying passengers' flows reducing exploitation expenses.

There are more compact and need fewer expenses as compared with diesel trains. The principles of the use of automotrises are:

- It is suggested that automotrises should not be used for long lines, i.e. for transporting at a distance up to $50-100 \mathrm{~km}$. Hence they are the most suitable ones for suburban transportations around Lithuania's biggest cities - Vilnius, Kaunas, Klaipeda and Šiauliai.

- It is expedient to use them on those roads which are distinguished for unintensive passengers' flows or they are not uniform, or it is not cost - effective to use diesel trains.

Automotrises are recommended to be used on the following roads: Vilnius - Gudagojis, Vilnius Valčiūnai, Vilnius - Lentvaris, Vilnius - Stasylos, Švenčionèliai - Turmantas, Kaunas - Jonava, Kaunas - Kaišiadorys, Kazlų Rūda - Kybartai, Šiauliai Radviliškis, Radviliškis - Mažeikiai, Klaipedda Vilkyčiai, Klaipėda - Šilutè, Klaipėda - Kretinga, Klaipėda - Pagègiai.

It is also expedient to use 6 automotrises in Vilnius zone, 4 - in Šiauliai and 2 in both Kaunas and Klaipeda zones. First of all automotrises should be used in Vilnius zone.

The carried out calculations have shown that the use of automotrises instead of diesel trains would enable us to reduce the conditional exploitation expenses to $44 \%$.

2. One more way of improving the passengers' transportation technologies as well as of improving the interaction between railway and road transport is the organization of combined "railway + bus" transportations. On the basis of many years research the author proposes to organize combined passengers' transportations "railway + bus" on the following routes: Vilnius - Kretinga (Palanga - by bus) Klaipeda and Vilnius - Marcinkonys - (Druskininkai -by bus).

On such routes passengers would be transferred from trains into buses, thus reducing exploitation expenses. On analogy passengers would be taken to trains and transferred into buses. It is expedient to introduce a single ticket for such kind of transportations and the reserved income should be distributed among drivers in accordance with the established requirements.

3. Another very important scientific way of improving transportation technologies suggested by the author, as well as that of improving the interaction between railway and road transport is the implementation of the fast local "railway + bus" communication.

It is proposed that the main flows of passengers on such routes as Vilnius - Kaunas, Kaunas Klaipeda, Vilnius - Varèna, Vilnius -Turmantas should be carried by fast trains and the local bus traffic should be matched with the railway traffic so that passengers could be conveyed within the region. This triggers a necessity to increase the speed of passenger trains. Besides, it is also very important to adequately coordinate the regional bus traffic with the train traffic on these routes.

4. When attempting to scientifically organize the country's internal passengers' transportation by road and rail, it is also crucial to implement one more principle proposed by the author, i.e. the construction of the logical journey chain "travelling + transferring". On the basis of scientific research it is advisable to match with each other the following:

- the traffic schedules of intercity buses and train routes as well as transfers from one route to another.

- to coordinate, as it was mentioned, the railway traffic schedules with the regional buses traffic schedules (the later should be coordinated in favour of the railway schedules).

In accordance with the coordinated the above mentioned traffic schedules of trains and buses, it is important to form the whole logical journey chain "travelling + transferring" for the passenger on the country's scale.

It is recommended to publish a book including the overall traffic schedules of buses and trains on all routes. The transfers from intercity buses into intercity trains and vice versa should be indicated as well as the transfers from intercity buses and trains into 
suburban buses and vice versa. Such visible information should be displayed at railway and bus stations.

The implementation of the above - mentioned principles of improving transportation technologies would improve passengers' transportations by both rail and bus, which would determine the growth of flows of passengers as well as income growth received for passengers' transportations.

\section{The implementation of new transportation tech- nologies in the Lithuanian railway transport}

The author put forward the idea of the implementation of super-fact railways in Lithuania as 1988. Due to the fast that two Kreta corridors extend all over our country (I - north - south and IX - west east) there is a possibility for the Lithuanian railways to join the European transport network of super-fast railways. The building of the European track for a super-fast railway line in I Kreta corridor is one of most important ways of joining it.

The research carried out by the author [8-12] shows that it is possible to build such super-fast railway in Lithuania. It would extend I Kreta corridor to Poland, Latvia, Estonia and Russia. In 1997 a super-fast railway line to Berlin was built. Its further track should be built from Berlin via Warsaw, Šeštokai, Kaunas, or Vilnius, Šiauliai, Riga, Tallinn with a branch to St Petersburg. Therefore, this project has to be conducted by all Baltic states and Poland as well. Russia should build the branch to St. Petersburg. The length of the international I Kreta corridor Warsaw - Šštokai Kaunas - Riga - Tallinn in Lithuania is 332,7 km (it consists of $191,9 \mathrm{~km}$ of single-way road districts and $140,8 \mathrm{~km}$ of two-way road sections).

The author suggests that the railway extending along I Kreta corridor across Lithuania should not be used only for passengers' transportation. The density of population in Lithuania is much lower than in Western Europe. Besides Lithuania itself is not big, that is why its people do not have a great need to travel long distances. As a result considerable flows of passengers that could ensure the pay-off of the funds spent for the building of such line (will not form). Thus, we should follow Germany's example, where the recoupment of the part of new lines is guaranteed only when cargo trains of a certain category are exploited which can travel up to $160 \mathrm{~km} / \mathrm{h}$ speed. An increase of speed of cargo trains sorts them in the cargo carriage market. Bearing in mind the example of foreign countries, the author suggests that a mixed type super-fast railway line in I Kreta corridor should be built, intended for both passengers and goods traffic. Cargo trains should be included into integrated scheme of passenger transportation carried out super-fast trains by identifying the so-called "windows" in the traffic schedule.

\section{The establishment of the prospective railway and road markets}

The author's carried out research has proved that in the process of increasing the communication speed and extending the passenger service on a train, the prospective market of transportations would assume the following shape [8-9]:

1. The routes for internal intercity transportations would be as follows: Vilnius - Šiauliai - Klaipèda; Vilnius - Kaunas; Vilnius - Turmantas; Vilnius Varèna; kaunas - Šiauliai - Klaipėda; Kaunas Kybartai; Šiauliai - Mažeikiai;

2. The routes for internal local transportations would be: Vilnius - Stasylos, Vilnius - Lentvaris, Vilnius - Kena, Vilnius - Trakai, Radviliškis - Šiauliai, Klaipèda - Kretinga, Klaipèda - Šilutè - Pagègiai.

The main flow of passengers travelling on the above - listed routes should be transported by rail.

3. Railway transport has to collaborate with road transport on the routes: Vilnius - Kretinga - (Palanga) - Klaipeda and Vilnius - Marcinkonys (Druskininkai), i.e. having changed from a railway transport means to a road one in Kretinga, passengers have to be further transported to Palanga (and from there to Kretinga), and passengers who are delivered to Marcinkonys by rail have to be further transported to Druskininkai by road (and from there back to Marcinkonys).

4. The main flows of passengers travelling on such routes as Vilnius - Kaunas, Kaunas - Klaipeda, Vilnius - Varena, Vilnius - Turmantas should be transported by rail whereas the internal road transport should convey them within the region as well as transport them close to the railway lines [13].

5. Railway transport will compete with road transport on such routes as Kaunas - Jonava, Šiauliai Rokiškis, Kaunas - Marijampole - Šeštokai.

6. Passengers will be conveyed by road transport on other internal distant and local communication routes.

\section{The research into the competition between road and rail transport and the assirance of equal condi- tions of the competition}

External research into the competition between road and rail transport and the assurance of equal conditions of the competition. Research highlighted the fact that road transport in Lithuania contains two important priorities comparing with rail transport and these priorities are given by the state itself. 
Lithuania must follow the EU, i.e. it is necessary to establish equal competing conditions for both road and rail transport. The author has prepared the following scientific principles to solve the above mentioned problems:

1) first of all, it is necessary to separate railway infrastructure from an operator, i.e. to separate rail network from operators that exploit it;

2) the next step is to establish an enterprise that owns infrastructure. This enterprise should be public, i.e. railway network should belong to the state;

3 ) the next stage is to ensure that the state maintains railway infrastructure and allocates investments. The following model of means accumulation for infrastructure is proposed: to introduce a tax for infrastructure - it should be paid by enterprises that use railway network. "Lithuanian railways" should pay too, because they would become an enterprise that exploit railway network. A big advantage of infrastructure separation is the possibility to attract private operators to railway, etc.

The investigation of internal competition and the assurance of competition conditions within one transport branch. Road transport. Long-term author's research proved that it is necessary to change the attitude to routes organisation. According to the author, routes should be treated as goods that a customer (state, municipality) should sell for operators on as favourable conditions as possible.

To ensure equal competition conditions operators for fulfilling of public service commitments are to be selected by tendering.

Tenders for urban bus routes in cities with more than 100 thousand inhabitants should be organised by transport agents, Transport council, in other cities and regions by municipalities or transport agents authorised by them.

Tenders for suburban bus routes should be organised by municipalities or transport agents authorised by them.

Railway transport. After the separation of infrastructure private operators will show up. Then for the assurance of equal competing conditions it is necessary to introduce these principles defined by the author: operators should be selected by tendering; terms of taxes for infrastructure should be equal for all operators.

\section{Conclusions}

1. Having evaluated the country's market of passenger transport, it was determined that the influence of transportation by inland water transport to this market is minimal, transportation by air transport does not influence the local market of the country and makes up a small part, i.e. 12,8 per cent, of international market, transportation by sea transport makes up only 2,4 per cent of international market. Thus, land transport makes up the main part of the country's market of passenger transport, i.e. it transports 99,5 percent of the country's passengers, 99,6 per cent of local passengers and 84,8 per cent of international passengers. Therefore, researching the development of passenger transportation, it is important to examine transportation by land.

2. During the period of 1991-2003 the number of passengers transported by the country's land transport was constantly decreasing. It was caused mainly by a rapid increase in rates and a number of individual automobiles, by the loss of the public transport prestige. However, having performed prognostications according to the methodology of finding an equation of irrectilinear regression it was determined that the volume of passenger transportation will increase again because of the influence of one main factor, i.e. the increase of gross domestic product.

3. Developing passenger transportation, it is very important to improve the interaction of road and railway transport. For this purpose it is expedient to apply prepared means to improve transportation technology, i.e. the organization of combined transportation "railway + bus" on the routes Vilnius - Kretinga - (Palanga) - Klaipèda and Vilnius - Marcinkonys (Druskininkai) and the organization of fast local communication "railway + bus" on the routes Vilnius Kaunas, Kaunas - Klaipeda, Vilnius - Varėna, Vilnius - Turmantas. Moreover, it is necessary to draw a logical chain ,travel + change” for a passenger on a country scale matching train and bus timetables for this purpose according to the prepared principles.

4. The application of other means improving transportation technologies, which were prepared on the basis of research, such as the use of automobile railway cars instead of Diesel trains, the application of modulus principle of automotrices, the organization of shuttle traffic of automotrices would help to reduce conditional exploitation expenditure, to thicken traffic intervals and to improve the conditions of passenger transportations at the same time.

5. The application of new modem transportation technologies, i.e. super fast railways, as it was suggested in this work would enable to broaden international transportations of passengers on a scientific basis and would create favourable conditions for the integration to the European system of passenger transportations. The following scientific principles were based by research: the track of super fast railways must be of a mixed character, i.e. it must transport both passengers and freight; the main sources of finances are the EU structural funds. 
6. Increasing communication speed and developing passenger service in railway transport its prospective market in interurban transportation would be the routes Vilnius - Šiauliai - Klaipeda, Vilnius Turmantas, Vilnius - Kaunas, Vilnius - Varena, Kaunas - Šiauliai - Klaipeda, Kaunas - Kybartai, Šiauliai - Mažeikiai, in local transportation the routes Vilnius - Stasylai, Vilnius - Lentvaris, Vilnius - Kena, Vilnius - Trakai, Radviliškis - Šiauliai, Klaipèda Kretinga, Klaipèda - Šilutè - Pagègiai, on other routes of remote and local communication road transport will dominate.

7. In order to improve the conditions of passenger transportation it is necessary to ensure equal competition conditions between road and railway transport and in every transport branch. The introduction of prepared principles ensuring equal competition conditions would help to reduce expenditure on transportation financing, would help the private operators to join the market, would annul the monopoly of separate companies.

8. For the public transport to function normally, legal relationships between the client and the operator must be legitimate. The implementation of prepared principles of contractual relationship between the customers (the state, municipalities) and the operators would help to turn passenger transportation into a normal business where the state would save money for public transport, passengers would get better transportation conditions and the operators could renew their fleets $[10,14,15]$.

9. On the basis of the research of this work the following documents were prepared: the development strategy of the public passenger transport of the Republic of Lithuania, the political study of passenger transportation by road transport, the outline of interaction conception between the branches op public passenger transport of the Republic of Lithuania, the regulations of issuing and use of licences for passenger transportation on regular road transport routes in the Republic of Lithuania.

\section{References}

1. Butkevičius, J.; Mazūra, M.; Ivankovas, V.; Mazūra, S. Analysis and forecast of the dynamics of passenger transportation by public land transport. Transport, Vol XIX, No 1, Vilnius: Technika, 2004, p. 3-8.

2. Butkevičius, J.; Žvirblis, A. The research on passengers ${ }^{\star}$ transportations by land transport and the formation of the formalised models. Transport, Vol XVII, No 2, Vilnius: Technika, 2003, p. 84-88. ISSN 1392-1533.

3. Butkevičius, J. Passenger transport market research in Lithuania. Transport and Telekomunication, Vol 5, No 2, Riga, 2004, p. 101-104 (in Russian).
4. Butkevičius, J. Modelling of the depedence of travel frequency on the lenght duration of a jorney. Improvement of city passenger transport systems. Transport, Vol XVII, No 6, Vilnius: Technika, 2002. ISSN 1392-1533.

5. Butkevičius, J.; Kliorè, A. The rationalization of passenger transport on railway track Vilnius - Kaunas. Transport Engineering (Transportas), No (1)10. Vilnius: Technika, 1995, p. 97-104 (in Lithuanian). ISSN 13921533.

6. Butkevičius, J. The rationalization of passenger transport by rail from Vilnius city to the east direction. Transport Engineering (Transportas), No 2(11). Vilnius: Technika, 1995, p. 72-77 (in Lithuanian). ISSN 13921533.

7. Butkevičius, J. The main trends of passenger transport by rail. Transport Engineering (Transportas), Vol XV, No 1. Vilnius: Technika, 2000, p. 29-32 (in Lithuanian). ISSN 1392-1533.

8. Butkevičius, J. The implementation of new carriage in the Lithuanian railway transport and establischment of the prospective market for railway and road transport. Transport, Vol XVIII, No 4, Vilnius: Technika, 2003, p. 168-173. ISSN 1392-1533.

9. Butkevičius, J. The improvement of passenger transport technologies and the implementation of new technologies. The article published in a collective monograph. In: Transport: technologies, economics, environment, health (Transportas: technologijos, ekonomika, aplinka, sveikata). Vilnius: Technika, 2003, p. 490-558 (in Lithuanian).

10. Butkevičius, J. Passenger transportation (Keleivių vežimai). Monograph. Vilnius: Technika, 2002. 416 p. ISBN 9986-05-567-9 (in Lithuanian).

11. Butkevičius, J. The development of high speed trains in the world and the perspectives of the development in Lithuania. Transport and Telekomunication, Vol 5, No 2, Riga, 2004, p. 105-110 (in Russian).

12. Butkevičius, J.; Musteikis, P. The establishment possibilities of the super high speed train network in Lithuania. OSShD magazine, No 6, Warsaw, 2002, p. 4 6 (in German).

13. Butkevičius, J. The perspectives and trends of interurban passenger transport by coaches and railways in Lithuania. In: Transport problems. Szczecin, University, Scientific works, Szczecin, 1994, p. 109-115 (in Polish) ISSN 1230-414XN.130.

14. Butkevičius, J. The improvement of public passenger transport organization, planning, financing and management in the Republic of Lithuania. Computer Modelling and New Technologies, Vol 6, No 1, Riga, 2002, p. 89-94 (in Russian). ISSN 1407-5806, ISSN 1407-5814.

15. Butkevičius, J. The interaction conception of Lithuania public passenger transport branches. Transport Engineering (Transportas), No 14, Vilnius: Technika, 1997, p. 4751 (in Lithuanian). ISSN 1392-1533. 